\section{Cytotoxicity, Antimicrobial and Antioxidant Studies of the Different Plant Parts of Mimosa Pudica}

Sadia Afreen Chowdhury, Jannatul Islam, Md. Mahfujur Rahaman, Md. Mostafizur Rahman, Nowshin Nowaz Rumzhum, Rebeka Sultana, Most. Nazma Parvin Laboratory of Pharmacognosy and Pharmacology Department of Pharmacy

Stamford University, Dhaka-1217, Bangladesh

\section{Corresponding Author \\ Sadia Afreen Chowdhury}

Lecturer

Stamford University Bangladesh

E-mail: sadia afreen chy@yahoo.com

Received-5 November 2008 Accepted for Publication- 24 November 2008

\begin{abstract}
The petroleum ether, chloroform and methanol crude extracts of the two different plant parts (aerial part and root) of Mimosa pudica (Mimosaceae) were screened in vitro for cytotoxicity studies by brine shrimp lethality bioassay and antimicrobial screening by disc diffusion method. The methanol crude extract of the aerial part was screened in vitro for antioxidant activity using the 1, 1-diphenyl-2-picrylhydrazyl-hydrate (DPPH) free radical scavenging assay. The petroleum ether and methanol crude extracts of the root showed potential cytotoxic activities ( $\mathrm{LC}_{50} 0.05 \mu \mathrm{g} / \mathrm{ml}$ and $0.035 \mu \mathrm{g} / \mathrm{ml}$ respectively) whereas the other extractives showed poor cytotoxicity. All the crude extracts showed poor activity or inactivity against the test microorganisms. On the other hand, the methanol crude extract of the aerial part showed moderate antioxidant activity $\left(\right.$ IC $_{50} 296.92$ $\mu \mathrm{g} / \mathrm{ml}$ ) compared to ascorbic acid $\left(\mathrm{IC}_{50} 131.29 \mu \mathrm{g} / \mathrm{ml}\right)$. The overall experimental results suggest the biologically active constituents present in the methanolic extract of Mimosa pudica and justify its use in folkloric remedies.
\end{abstract}

Key Words: Mimosa pudica, Mimosaceae, Cytotoxicity, Antimicrobial, DPPH, Antioxidant.

\title{
INTRODUCTION
}

Plants have been the traditional source of raw materials for medicine. A rich heritage of knowledge to preventive and curative medicines was available in ancient scholastic works included in the Atharva veda, Charaka, Sushruta, etc. An estimate suggests that about 13,000 plant species worldwide are known to have use as drugs. The trend of using natural products has increased and the active plant extracts are frequently for new drug discoveries and for the presence of antimicrobials (Das et al., 1999). In recent years one of the areas which attracted a great deal of attention is the possible therapeutic potential of antioxidants in controlling degenerative diseases associated with marked oxidative damage. Several plant extracts and different classes of phytochemicals have been found to have quite prominent antioxidant activity (Sreejayan et al., 1997, Vani et al., 1997, Tripathi et al., 1996, Larson, 1998). Mimosa pudica (Bengali name Lajjabati Lata, Lajanti; English name - Sensitive plant; Family- Mimosaceae) is a stout strangling prostrate shrubby plant with compound leaves sensitive to touch, spinous stipules and globose pinkish flower heads, grows as a weed in almost all parts of the country (Ghani, 2003). Leaves and stems of the plant have been reported to contain an alkaloid, mimosine; leaves also contain mucilage and root, tannins (Ghani, 2003). The plants also contain turgorins. M. pudica is regarded as diuretic, astringent and antispasmodic. Leaves and roots are used in the treatment of piles and fistula. Paste of leaves is applied to hydrocele. Cotton impregnated with juice of leaves is used for dressing sinus. Plant is also useful in the treatment of sore gum and is used as a blood purifier. It is also used for treating convulsions of children (Ghani, 2003). Few chemical and biological studies have been carried out on this plant (Genest et al., 2008, Yuan et al., 2007, Balakrishnan et al., 2006, Dinda et al., 2006, Bum et al., 2004, Kirk et al., 2003). In this paper, the cytotoxicity, antimicrobial activity and the preliminary antioxidant activities of the organic extractives are being reported.

\section{MATERIALS AND METHODS}

\section{Plant material}

M. pudica was collected from Sirajgong in July, 2007. The plant was identified by Dr. Mahbuba Khanam, Principle Scientific Officer, Bangladesh National Herbarium, Dhaka. A voucher specimen 
has been deposited in Bangladesh National Herbarium (DCAB accession no. 32887). The aerial part and the root of the plant was first sun dried and then ground into coarse powder.

\section{Extraction}

The powdered aerial part $(260 \mathrm{~g})$ of $M$. pudica was separately extracted to exhaustion in a Soxhlet apparatus at $50^{\circ} \mathrm{C}$ with petroleum ether, then chloroform and finally with methanol. All the extracts were filtered through a cotton plug followed by Whitman filter paper number 1 and then concentrated by using a rotary evaporator at low temperature $\left(40-50{ }^{\circ} \mathrm{C}\right)$ and reduced pressure to provide petroleum ether $(4.0 \mathrm{~g})$, chloroform $(3.43 \mathrm{~g})$ and methanol $(6.18 \mathrm{~g})$ extractives. Similarly the powdered root $(260 \mathrm{~g})$ of the plant was extracted by the same procedure with petroleum ether, then chloroform and finally with methanol and then concentrated by using a rotary evaporator at low temperature $\left(40-50{ }^{\circ} \mathrm{C}\right)$ and reduced pressure to provide petroleum ether $(3.26 \mathrm{~g})$, chloroform $(2.98 \mathrm{~g})$ and methanol $(3.87 \mathrm{~g})$ extractives.

\section{Biological screening}

\section{Cytotoxicity study}

Brine shrimp lethality bioassay (Persoone, 1980) technique was applied for the determination of cytotoxic property of petroleum ether, chloroform and methanol extractives of both the aerial part and root of the plant M. pudica.

\section{Preparation of positive control group}

Vincristine sulphate was used as the positive control. Measured amount of the vincristine sulphate was dissolved in DMSO to get an initial concentration of $20 \mu \mathrm{g} / \mathrm{ml}$ from which serial dilutions are made using DMSO to get $10 \mu \mathrm{g} / \mathrm{ml}, 5 \mu \mathrm{g} / \mathrm{ml}, 2.5 \mu \mathrm{g} / \mathrm{ml}, 1.25 \mu \mathrm{g} / \mathrm{ml}, 0.625 \mu \mathrm{g} / \mathrm{ml}, 0.3125 \mu \mathrm{g} / \mathrm{ml}$, $0.15625 \mu \mathrm{g} / \mathrm{ml}, 0.078125 \mu \mathrm{g} / \mathrm{ml}$ and $0.0390 \mu \mathrm{g} / \mathrm{ml}$. Then the positive control solutions are added to the premarked vials containing ten living brine shrimp nauplii in $5 \mathrm{ml}$ simulated sea water to get the positive control groups

\section{Preparation of negative control group}

$30 \mu \mathrm{l}$ of DMSO was added to each of three premarked glass vials containing $5 \mathrm{ml}$ of simulated seawater and 10 shrimp nauplii to use as control groups. If the brine shrimps in these vials show a rapid mortality rate, then the test is considered as invalid as the nauplii died due to some reason other than the cytotoxicity of the compounds.

\section{Counting of nauplii}

After 24 hours, the vials were inspected using a magnifying glass and the number of survived nauplii in each vial were counted. From this data, the percent (\%) of lethality of the brine shrimp nauplii was calculated for each concentration.

\section{Antimicrobial assay}

The disc diffusion method (Bauer et al., 1966) was used to test antimicrobial activity against thirteen bacteria and three fungi (Table-2). Solutions of known concentration $(\mathrm{mg} / \mathrm{ml})$ of the test samples were made by dissolving measured amount of the samples in calculated volume of solvents. Dried and sterilized filter paper disc (6 $\mathrm{mm}$ diameter) were then impregnated with known amounts of the test substances using micropipette. Discs containing the test material were placed on nutrient agar medium uniformly seeded with the test microorganisms. Standard antibiotic discs (kanamycin $30 \mu \mathrm{g} / \mathrm{disc}$ ) and blank discs (impregnated with solvents) were used as a positive and negative control. These plates were then kept at low temperature $\left(4^{\circ} \mathrm{C}\right)$ for $24 \mathrm{~h}$ to allow maximum diffusion. There is a gradual change in concentration in the media surrounding discs. The plates were then incubated at $37^{\circ} \mathrm{C}$ for $24 \mathrm{~h}$ to allow maximum growth of the organisms. The test materials having antimicrobial activity inhibited the growth of the microorganisms and a clear, distinct zone of inhibition was visualized surrounding the medium. The antimicrobial activity of the test agent was determined by measuring the diameter of zone of inhibition expressed in millimeter. The experiment is carried out three times and the mean of the reading is required (Bauer et al., 1966).

\section{Screening for antioxidant activity}

Antioxidant activities of the aerial part of methanol extract was determined on the basis of their scavenging potential of the stable DPPH free radical in both qualitative and quantitative assay. 
i) Qualitative assay: A suitably diluted stock solutions were spotted on pre-coated silica gel TLC plates and the plates were developed in solvent systems of different polarities (polar, medium polar and non-polar) to resolve polar and non-polar components of the extracts. The plates were dried at room temperature and were sprayed with $0.02 \%$ DPPH in ethanol. Bleaching of DPPH by the resolved band was observed for 10 minutes and the color changes (yellow on purple background) were noted (Sadhu et al. 2003).

ii) Quantitative assay: Quantitative assay was performed on the basis of the modified method (Gupta et al. 2003). Stock solution $(10 \mathrm{mg} / \mathrm{ml})$ of the plant extracts were prepared in ethanol from which serial dilutions were carried out to obtain concentrations of $1,5,10,50,100,500 \mu \mathrm{g} / \mathrm{ml}$. Diluted solutions (2 ml) were added to $2 \mathrm{ml}$ of a $0.004 \%$ ethanol solutions of DPPH (Aldrich, USA), mixed and allowed to stand at $25{ }^{\circ} \mathrm{C}$ for $30 \mathrm{~min}$ for reaction to occur. The absorbance was determined as $517 \mathrm{~nm}$ and from these values corresponding percentage of inhibitions were calculated. Then $\%$ inhibitions were plotted against log concentration and from the graph $\mathrm{IC}_{50}$ was calculated. The experiment was performed in triplicate and average absorption was noted for each concentration. Ascorbic acid (Loba, India) was used as positive control.

\section{RESULTS}

\section{Cytotoxicity study}

Following the procedure of Mayer (Larson, 1988), the lethality of all the crude extracts to brine shrimp were determined on $A$. salina. Table 1 shows the results of the brine shrimp lethality testing after 24 hours of exposure to the samples and the positive control, vincristine sulphate. The $\mathrm{LC}_{50}$ obtained from the best-fit line slope were found to be $23.44 \mu \mathrm{g} / \mathrm{ml}, 20.89 \mu \mathrm{g} / \mathrm{ml}$ and $80.0 \mu \mathrm{g} / \mathrm{ml}$ for petroleum ether, chloroform and methenol crude extract of the aerial part of the plant and $0.05 \mu \mathrm{g} / \mathrm{ml}, 78.87 \mu \mathrm{g} / \mathrm{ml}$ and $0.035 \mu \mathrm{g} / \mathrm{ml}$ for petroleum ether, chloroform and methenol crude extract of the root respectively.

\section{Antimicrobial assay}

The petroleum ether, chloroform and methanol crude extracts (500 $\mu \mathrm{g} / \mathrm{disc})$ of the aerial part and root of $M$. pudica were screened against thirteen bacteria and three fungi (Table 2) for antimicrobial activities by disc diffusion method.

\section{Antioxidant activity}

DPPH is one of the free radicals widely used for testing preliminary radical scavenging activity of a compound or a plant extract.

i) Qualitative assay: The color changes (yellow on purple background) on the TLC plates were observed due to the bleaching of DPPH by the resolved bands.

ii) Quantitative assay: The methanol extract of the aerial part of Mimosa pudica showed moderate antioxidant activity with the $\mathrm{IC}_{50}$ value of $296.92 \mu \mathrm{g} / \mathrm{ml}$ against DPPH free radical (Table$3)$. It is evident that the extract possesses antioxidant activity.

\section{DISCUSSION}

\section{Cytotoxicity study}

In comparison with the positive control (vincristine sulphate), the cytotoxicity exhibited by the petroleum ether and methanol crude extract of the root shows potent activity whereas the other extractives shows poor activity. This clearly indicates the presence of potent bioactive principles in this crude extract of which might be very useful as antiproliferative, antitumor, pesticidal and other bioactive agents (Meyer et al., 1982).

\section{Antimicrobial assay}

None of the crude extracts of M.pudica demonstrated significant inhibition of growth of the test microorganisms. This was probably due to the development of partial or complete resistance of the microorganisms against the test samples, which might be the indiscriminate use of antibacterial agents (Chowdhury et al., 2008). 


\section{Antioxidant activity}

Most of the tannins, flavanoids and phenolic compounds may be responsible for antioxidants properties of many plants (Larson, 1988). In these experiments, antiradical activity may be due to the presence of antioxidant principles in the extract. The free radical scavenging property may be one of the mechanisms by which this plant is effective in its ethno pharmacological uses against different ailments. Further studies comprising of phytochemical investigations of the used plant and evaluation for antioxidant activity using other methods (e.g. various biochemical assays both in vivo and in vitro) are essential to characterize them as biological antioxidants.

Table 1: $L_{50}$ data of the test samples of $M$. pudica in brine shrimp lethality bioassay

\begin{tabular}{ccc}
\hline Plant parts & Crude extracts & LC $_{50}(\boldsymbol{\mu g} / \mathbf{m l})$ \\
\hline Aerial part & Petroleum ether & 23.44 \\
& Chloroform & 20.89 \\
\cline { 2 - 3 } & Methanol & 80.0 \\
\cline { 2 - 3 } & Petroleum ether & 0.05 \\
\cline { 2 - 3 } Root & Chloroform & 78.87 \\
\cline { 2 - 3 } & Methanol & 0.035 \\
\cline { 2 - 3 } & Vincristine sulphate & 0.35 \\
\hline
\end{tabular}

Table 2: Antimicrobial activities of the extractives of $M$. pudica and Kanamycin

\begin{tabular}{|c|c|c|c|c|c|c|c|c|c|c|c|c|c|c|c|c|c|}
\hline \multirow{3}{*}{$\begin{array}{l}\text { Plant } \\
\text { parts }\end{array}$} & \multirow{3}{*}{$\begin{array}{c}\text { Extracts } \\
\text { (500 } \\
\mu \mathrm{g} / \text { disc) }\end{array}$} & \multicolumn{16}{|c|}{ Zone of inhibition in $\mathrm{mm}$} \\
\hline & & \multicolumn{13}{|c|}{ Bacteria } & \multicolumn{3}{|c|}{ Fungi } \\
\hline & & $\begin{array}{l}\text { B } \\
\text { C }\end{array}$ & BM & $\begin{array}{l}B \\
S\end{array}$ & $\begin{array}{l}S \\
A\end{array}$ & $\begin{array}{l}S \\
L\end{array}$ & EC & $\begin{array}{l}\mathbf{P} \\
\mathbf{A}\end{array}$ & $\begin{array}{l}S \\
P\end{array}$ & $\begin{array}{l}S \\
T\end{array}$ & $\begin{array}{l}S \\
B\end{array}$ & $\begin{array}{l}\text { S } \\
\text { D }\end{array}$ & VM & VP & $\begin{array}{l}C \\
A\end{array}$ & $\begin{array}{l}A \\
R\end{array}$ & $\begin{array}{l}S \\
C\end{array}$ \\
\hline \multirow{3}{*}{$\begin{array}{l}\text { Aeria } \\
\text { I part }\end{array}$} & PET & $\ldots$ & $\ldots$ & 7 & 7 & $\ldots$ & $\ldots$ & $\ldots$ & 7 & 6 & $\ldots$ & 6 & $\ldots$ & $\ldots$ & 8 & $\ldots$ & $\ldots$ \\
\hline & CHL & 6 & $\ldots$ & $\ldots$ & $\ldots$ & 6 & 6 & $\ldots$ & $\ldots$ & $\ldots$ & $\ldots$ & $\ldots$ & 7 & $\ldots$ & $\ldots$ & 7 & $\ldots$ \\
\hline & ME & $\ldots$ & 7 & 6 & $\ldots$ & $\ldots$ & $\ldots$ & 6 & $\ldots$ & $\ldots$ & 7 & $\ldots$ & $\ldots$ & $\ldots$ & 6 & $\ldots$ & $\ldots$ \\
\hline \multirow[t]{3}{*}{ Root } & PET & $\ldots$ & $\ldots$ & $\ldots$ & $\ldots$ & 7 & $\ldots$ & 7 & $\ldots$ & 7 & $\ldots$ & 8 & 7 & $\ldots$ & $\ldots$ & $\ldots$ & 7 \\
\hline & CHL & $\ldots$ & $\ldots$ & $\ldots$ & $\ldots$ & $\ldots$ & 6 & $\ldots$ & $\ldots$ & $\ldots$ & $\ldots$ & $\ldots$ & $\ldots$ & $\ldots$ & $\ldots$ & 6 & $\ldots$ \\
\hline & ME & 7 & 6 & 6 & $\ldots$ & 7 & $\ldots$ & $\ldots$ & 6 & $\ldots$ & 6 & 7 & $\ldots$ & $\ldots$ & $\ldots$ & $\ldots$ & $\ldots$ \\
\hline $\begin{array}{l}\text { Stan } \\
\text { dard }\end{array}$ & $\begin{array}{c}\text { KM (30 } \\
\mu \mathrm{g} / \mathrm{disc}))\end{array}$ & 36 & 35 & 35 & 34 & 39 & 37 & 37 & 38 & 35 & 36 & 37 & 36 & 35 & 35 & 36 & 36 \\
\hline
\end{tabular}

$\mathrm{BC}=$ Bacillus cereus (BTCC-19), BM=Bacillus megaterium (BTCC-18), BS=Bacillus subtilis, $\mathrm{SA}=$ Staphylococcus aureus (BTCC-43), SL=Sarcina lutea (ATCC-9341), EC=Escherichia coli (BTCC-172), PA=Pseudomonas aeruginosa (BTCC1252), $\mathrm{SP}=$ Salmonella paratyphi, $\mathrm{ST}=$ Salmonella typhi, $\mathrm{SB}=$ Shigella boydii, $\mathrm{SD}=$ Shigella dysenteriae, $\mathrm{VM}=$ Vibrio mimicus, $\mathrm{VP}=$ Vibrio parahemolyticus, $\mathrm{CA}=$ Candida albicans, $\mathrm{AN}=$ Aspergillus niger, $\mathrm{SC}=$ Sacharomyces cerevacae, $\mathrm{PET}=\mathrm{Petroleum}$ ether, $\mathrm{CHL}=$ Chloroform, $\mathrm{ME}=$ Methanol

“..." Indicates no sensitivity

Table 3: Evaluation of antioxidant activity of methanolic extract of the aerial part of M. pudica

\begin{tabular}{ccc}
\hline Concentration $(\boldsymbol{\mu g} / \mathbf{m l})$ & $\begin{array}{c}\text { \% inhibition by Methanol extract } \\
\text { (aerial part) }(\text { mean } \pm \text { SD) }\end{array}$ & $\begin{array}{c}\text { \% inhibition by } \\
\text { Ascorbic acid }\end{array}$ \\
\hline 1 & $11.22 \pm 0.0055$ & $44.91 \pm 0.92$ \\
5 & $15.89 \pm 0.011$ & $47.95 \pm 0.98$ \\
10 & $20.128 \pm 0.008$ & $53.86 \pm 1.78$ \\
50 & $31.731 \pm 0.0085$ & $56.295 \pm 1.32$ \\
100 & $57.243 \pm 0.0055$ & $63.49 \pm 1.51$ \\
500 & $65.064 \pm 0.0055$ & $68.03 \pm 0.81$ \\
\hline $\mathbf{I C}_{\mathbf{5 0}}(\boldsymbol{\mu} \mathbf{g} / \mathbf{m l})$ & 296.92 & 131.29 \\
\hline
\end{tabular}




\section{ACKNOWLEDGEMENTS}

Authors are grateful to the authority of Stamford University Bangladesh and the Chairman, Department of Pharmacy of the same for extending their cordial support to perform these investigations.

\section{REFERENCES}

Balakrishnan N, Bhasker VH, Jayakar B, Sangameswaran B. (2006) Antibacterial activity of Mimosa pudia, Aegle marmelos and Sida cordifolia. Pharmacog Mag. 2(7): 198-199.

Bauer AW, Kirby WMM, Sherris JC, Turck, M. (1966) Antibiotic susceptibility testing by a standardized single disc method. Am. J. Clin. Pathol. 45: 493-496.

Bum EN, Dawack DL, Schmutz M, Rakotonorina A, Rakotonorina VS, Portet C, Jeker A, Olpe HR, Herding P. (2004) Anticonvulsant activity of Mimosa pudica decoction. Fitoterapia. 75: 309-314.

Chowdhury SA, Sohrab MH, Haque MR, Choudhury MH, Rashid MA. Phytochemical and biological investigations of Polygonum lanatum. Orien Pharm Exp Med. 8(1): 97-102.

Das S, Das S, Pal S, Mujib A, Dey S. (1999) Biotechnology of medicinal plants- Recent advances and potential. $1^{\text {st }}$ Ed. Vol II. pp. 126-139. UK992 Publications, Hydarabad.

Dinda B, Gosh B, Arima S, Sato N, Harigaya Y (2006) Steroids and terpinoids from Mimosa pudica roots. J Indian Chem. Soc. 83: 1044-1046.

Genest S, Kerr C, Shah A, Rahman MM, Saif-E-Naser EMM, Nigam P, Nahar L, Sarker SD. (2008) Comparative bioactivity studies on two Mimosa species. Bol. Latinoam Caribe. Plant Med Aromaticus. 7(1): 38-43.

Ghani A. (2003) Medicinal Plants of Bangladesh, $2^{\text {nd }}$ Ed. pp. 302-303. The Asiatic Society of Bangladesh, Dhaka.

Gupta M, Mazumder UK, Sivahkumar T, Vamis MLM, Karki S, Sambathkumar R, Manikadan I. (2003) Antioxidant and anti-inflammatory activities of Acalypha fruticosa. Nig. J. Prod. Med 7: 25-29.

Kirk LF, Moller MV, Christensen J, Steak D, Ekpe P, Jaroszewski KW. (2003) A 5- deoxuflavonol derivatives in Mimosa pudica. Biochem Systamatics Ecol. 31: 103-105.

Larson RA. (1988) The antioxidants of higher plants. Phytochemistry 27: 969-978.

Meyer BN, Ferringm NR, Puam JE, Lacobsen LB, Nichols DE, MeLaughlin JL. (1982) Brine shrimp: a convenient general bioassay for active constituents. Planta Medica. 45: 31-32.

Persoone G. (1980) Proceeding of the International Symposium on Brine Shrimp, Artemia Salina, Vols. 1-3. Universa Press, Witteren, Belgium.

Sadhu SK, Okuyama E, Fujimoto H, Ishibashi M. (2003) Separation of Leucas aspera, a medicinal plant of Bangladesh, guided by Prostaglandin inhibitory and Antioxidant activities. Chem Pharm Bull. 51: 595-598.

Sreejayan N, Rao MNA. (1997) Nitric oxide scavenging by curcuminoids. J Pharm Pharmacol. 49: 105-107.

Tripathi YB, Chaurasia S, Tripathi E, Upadhyay A, Dubey GP. (1996) Bacopa monniera Linn, As an antioxidant: Mechanism of action. Ind J Exp Biol. 34: 523-526.

Vani T, Rajani M, Sarker S, Shishoo CJ. (1997) Antioxidant properties of the Ayurvedic formulation Triphala and its constituents. Int J Prarmacognosy. 35: 313-317.

Yuan K, Jia A, Lu JL, Zhu JX. (2007) Structural identification of new C-glycosylflavones from Mimosa pudica. Chin J An Chem. 35: 739-742. 